\title{
1. Mergers and acquisitions: a cyclical and legal phenomenon ${ }^{1}$ \\ Claire A. Hill, Brian J.M. Quinn and \\ Steven Davidoff Solomon
}

Mergers and acquisitions (M\&A) have a rich history in the American economy. Over the course of the past century and a half, merger activity has proceeded in waves, each wave inevitably followed by a regulatory and legal response. Merger activity emerged during the late nineteenth century. The succeeding trust era, characterized by monopolies and frenetic acquisition activity, resulted in new regulations in the 1890s and early nineteenth century. Merger activity created vast conglomerates during the 1960s. During the 1970s and 1980s, the leveraged buyout boom led to the development of modern M\&A legal doctrine. The late 1980s and 1990s saw the embracing of new participants such as private equity firms. Today, the Internet Age and globalization have led to the current M\&A market, characterized by transactions that are global, very large (multi-billion dollar), and sometimes both.

\section{AN EARLY EXAMPLE OF U.S. MERGER ACTIVITY: THE ERIE WAR}

Following the Civil War and lasting through the Panic of 1873, the railroad industry underwent a period of growth as federal money flowed into the South to rebuild railroad stock. Estimates put the number of railroad organizations at the time in the thousands. Simultaneously and in part to meet the needs of these new organizations, a national capital market, centered around the New York Stock Exchange, began to develop. It was at this point that the U.S. mergers and acquisitions market began; yet, there was little law governing the field. The war for the Erie railroad illustrates the unregulated nature of the takeover market during this time period.

1 This chapter is adapted from Chapter 1 of Mergers and Acquisitions: Law, Theory and Practice, by Claire Hill, Brian JM Quinn and Steven Davidoff Solomon (West 2016); permission to use this material is gratefully acknowledged. 
Commodore Cornelius Vanderbilt purchased control of the New York and Harlem Railroad and the New York and Hudson Railroad in 1862. His control became apparent in late 1867 when he was elected President of New York Central Railroad and gained permission to consolidate his stakes into the New York Central and the Hudson River Railroad. By issuing watered stock, stock that is sold with a face value greater than its actual value, Vanderbilt was able to pay dividends to his shareholders even through the depression of the 1870s.

Meanwhile, the Erie Railroad, Vanderbilt's main competitor in the state, was controlled by Daniel Drew, a former cattle driver who in earlier years had been Vanderbilt's rival in the steamboat industry. Drew was aided by Jim Fisk and Jay Gould; the three were known as the 'Erie Gang'. Fisk was a stockbroker from Vermont who had a reputation for eccentricity; he was portrayed by Edward Arnold in the 1937 film, The Toast of New York. Gould was introverted and is often portrayed in contemporary media as a sinister, villainous genius. Fisk and Gould had already helped Drew sell Erie Railroad bonds for eight times their true value.

Vanderbilt was eager to expand and take control of the Erie Railroad, so the Erie Gang issued 100,000 new shares converted from the overvalued bonds to sell to the Commodore. By issuing additional shares to dilute Vanderbilt's position and thus prevent a takeover, the Erie Gang anticipated a maneuver that would become known in the modern era as a 'shareholder rights plan' or a 'poison pill'.

Upon discovering he had been cheated, Vanderbilt obtained a warrant to arrest Drew, Fisk, and Gould from his friend, Judge George Barnard. However, the trio took refuge in a hotel in Jersey City, New Jersey. The Erie Gang also took over \$7 million of Erie Railroad's funds in addition to unissued Erie Railroad stock. Vanderbilt was ready for battle, literally. The Commodore sent armed henchmen to attack the Erie Gang, but the gang fought back, even mounting cannons outside their refuge in New Jersey. The battle was ultimately won not with the sword, but with the pen and money: the Erie Gang, with the assistance of Senator William Tweed (aka 'Boss Tweed') and a bribe of a half a million dollars, convinced the New York legislature to enact legislation validating their actions. A New York Times article describes what happened next. The article discusses a cartoon, which is reproduced on page 15.

Despite their legislative victory over Vanderbilt, the members of the Erie Gang saw only short-lived success after the Erie Wars:

Drew, now replaced in top Erie leadership by Gould, turned to less successful exploits on Wall Street, where he was finally ruined in the Panic of 1873, left with little more than his Bibles, hymnbooks, and sealskin coat. Fisk, the new 


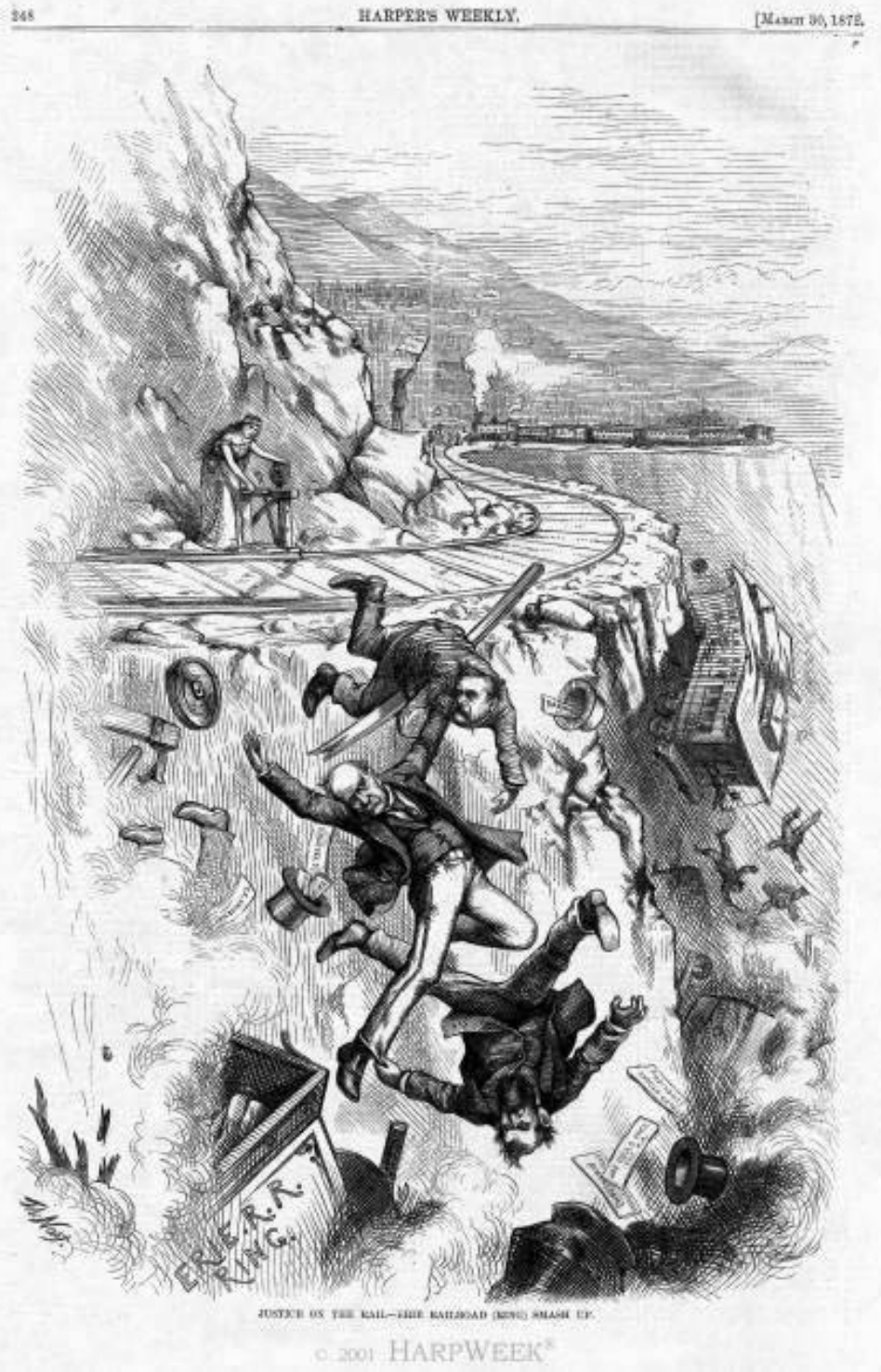

Figure 1.1 Justice on the rail: the Erie Railed (Ring) Smash Up 
vice-president, was known as 'Prince of Erie' and had a marble and gilded office in Pike's Opera House, which he and Gould rented to Erie at the not too modest rate of $\$ 75,000$ a month. He went on to be 'Admiral' of his own steamship line and Colonel of the 9th Regiment, New York National Guard. But his flamboyant career was ended early in 1872 , when he was shot by a rival for the affection of his favorite mistress, Josie Mansfield. The Erie Railroad lay in ruins, and Gould soon took his profits elsewhere. (Stover 1997: 105)

On March 11, 1872, the Erie Ring was broken and a new board of directors took over the Erie Railroad Company, with Gould formally resigning as president the next day. In the cartoon's background, the new board of directors takes the form of an incoming train whose path has been cleared by Justice at the switch. General John Dix (the engine) is the new president; S.L.M. Barlow (second car), the new counselor; William Watts Sherman (fifth car), the new treasurer; and O.H.P. Arches (sixth car), who spearheaded the takeover, was reelected vice-president. H.M. Otis was reappointed secretary.

Below Judge Barnard in the cartoon is David Dudley Field, chief counsel for both the Erie Ring and the Tweed Ring. To the left of Field is his law partner, Thomas G. Shearman, whose upper body is obscured by the smoke and dust of the crash. In 1873, Shearman left Field to partner with John Sterling, and in 1875 counseled Gould on the financier's attempted takeover of the Union Pacific Railroad. Today, Shearman \& Sterling is a prestigious, international law firm. Plummeting upside down at the bottom of the picture is Jay Gould. ${ }^{2}$

\section{FIRST AND SECOND WAVES OF U.S. MERGER ACTIVITY: THE RISE OF ANTITRUST REGULATION AND THE TRUSTBUSTERS}

The first merger wave came in the late 1800s. Large corporations combined to form trusts, merging diverse enterprises in order to control production and pricing. These combinations were in select industries such as oil, sugar, and steel, and were for the most part horizontal (that is, in the same industry), resulting in a highly concentrated industry. John Moody calculated that during this wave, roughly 5,300 industrial sites were consolidated into just 318 industrial trusts (Moody 1904). During this time

2 Robert C. Kennedy, 'On This Day', N.Y. Times, available at http://www. nytimes.com/learning/general/onthisday/harp/0330.html. The cartoon, reprinted from the article, is originally from Thomas Nast, 'Justice on the Rail - Erie Railroad (Ring) Smash Up', Harper's Weekly, Mar. 30, 1872. 
period, Standard Oil of New Jersey consolidated the oil industry, and U.S. Steel, at the behest of J.P. Morgan, consolidated the steel industry; they each controlled over three-quarters of their respective industries.

In response to this massive consolidation of industries into trusts and monopolies, Congress for the first time began to regulate takeovers from an antitrust perspective. Three key regulatory actions included the enactment of the Sherman Antitrust Act in 1905, the enactment of the Clayton Antitrust Act in 1914, and the creation of the Federal Trade Commission (FTC) in 1914.

\subsection{Sherman Antitrust Act}

The Sherman Antitrust Act makes contracts, trusts, or conspiracies that unreasonably restrain competition and that affect interstate commerce illegal. The Act also makes it a felony to 'monopolize, or attempt to monopolize, or combine or conspire with any other person or persons, to monopolize any part of the trade or commerce among the several States, or with foreign nations' (15 U.S.C. §2).

Although the Sherman Act was enacted in 1890, the Department of Justice (DOJ) and the courts were reluctant to enforce it until Theodore Roosevelt became president.

During the first decade of the Sherman Act's enforcement, the U.S. Supreme Court was indifferent to the creation and exercise of monopoly power. In cases such as United States v. E.C. Knight Co., the Court declined to prohibit consolidation of ninety-eight percent of the country's sugar refining capacity in the hands of the Sugar Trust. Almost another decade passed before the Court blocked a merger which would create a monopoly; in 1904, the Court ruled in favor of the DOJ in its Sherman Act challenge to the Great Northern and Northern Pacific railways combination. President Theodore Roosevelt, a man often depicted in political cartoons as the ultimate trustbuster, had urged the DOJ to sue the railways. In the 1904 election, Roosevelt described the Great Northern case as one of the 'great achievements of [his] administration'. Roosevelt's contemporaneous statements also recognized, however, that combinations could produce scale and scope efficiencies that benefited the consumer. (Gotts 2005: 456-7)

Although the effectiveness of President Roosevelt's actions to break up the trusts is debated, in the popular mind he is still viewed as the President who began and led the effort to do so. 


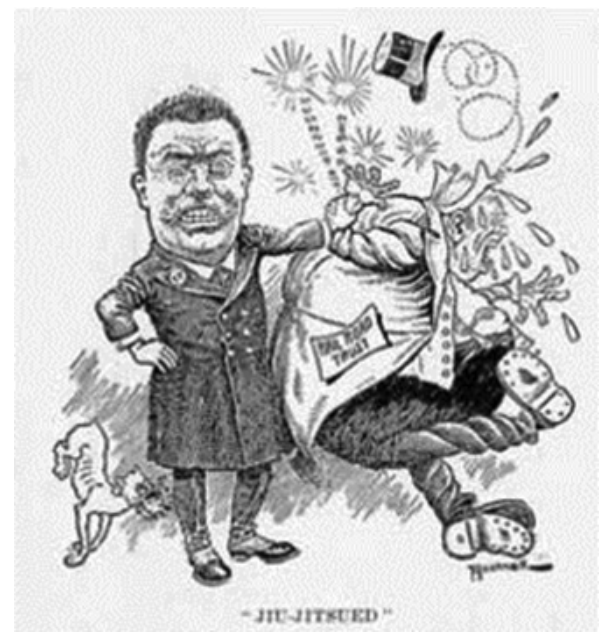

\section{Figure 1.2 Theodore Roosevelt ${ }^{3}$}

In 1911, perhaps the greatest victory of the trust busters occurred when the Supreme Court, in Standard Oil Co. of New Jersey v. United States, 221 U.S. 1 (1911), ruled that the Standard Oil trust was illegal under the Sherman Antitrust Act. Standard Oil was subsequently split up into 34 different companies. Nonetheless, trusts remained a significant public issue. In the 1912 Presidential campaign, Woodrow Wilson challenged Roosevelt's strategy regarding trusts.

Like Roosevelt, Wilson viewed the growth of large corporations as an inevitable component of economic progress. And, like Roosevelt, he supported an active role for the government in overseeing the economic system. Unlike Roosevelt, however, Wilson shared Taft's view that the federal government should only police the activities of business, not direct the economy. Wilson believed that if the government could prevent the abuses of monopoly power, natural competition would prevail and make it unnecessary for the government to actively regulate the economy. Unlike Taft, however, Wilson did not wish to leave the policing to the judicial branch. He preferred instead the creation of administrative agencies with this oversight function. Wilson's philosophy, then, contained elements of both Lockean liberalism and republicanism. This combined philosophy relegated the government to playing a largely reactionary role - so long as business behaved properly, government would not interfere in its operations. The result was piecemeal regulation, rather than a central plan for coordinating the economy. (Ballam 1994: 619-20)

3 T. Roosevelt cartoon, 'Jiu-Jitsued': American cartoon, c1906, available at http://fineartamerica.com/featured/1-t-roosevelt-cartoon-granger.html 
A second wave of mergers began during Wilson's presidency, and continued until the Great Depression. During this time period, heightened antitrust enforcement impeded horizontal mergers (mergers among competitors). Instead, in this wave the predominant transaction form was a vertical merger (mergers among companies in a supply chain), as oligopolies were formed. As noted, Wilson's presidency saw continued vigor in regulating and breaking up the trusts, with the enactment of the Clayton Antitrust Act and the Federal Trade Commission Act.

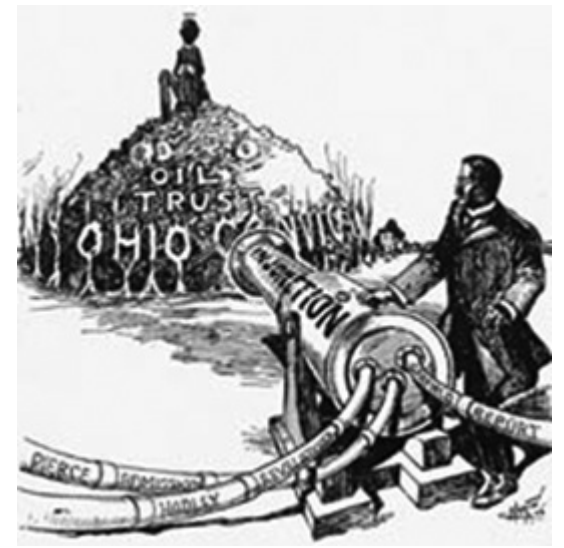

Figure 1.3 Roosevelt aiming a cannon at the oil trust ${ }^{4}$

\subsection{Clayton Antitrust Act}

The Clayton Antitrust Act, enacted in 1914, expanded on the Sherman Act. The Act made substantive additions related to four topics: price discrimination, exclusive dealings and tying, mergers and acquisitions, and corporate governance. However, despite its attempts to enhance the Sherman Act, the Clayton Antitrust Act came under fire for failing to do much of anything (Commentary 1930).

\subsection{Federal Trade Commission}

The FTC was created by the Federal Trade Commission Act; the Act was enacted in 1914, a month before the Clayton Act. The FTC is comprised of

$4 \quad$ St Louis Post-Dispatch, Nov. 1906. 
five commissioners, with no more than three commissioners from the same political party. ${ }^{5}$ In addition to enforcing the Federal Trade Commission Act, the FTC was granted wide investigatory and supervisory powers relating to U.S. antitrust enforcement.

\subsection{The Great Depression and Subsequent Reform}

The stock market crash of 1929 brought on the Great Depression and exposed numerous fraudulent practices in the period leading up to the crash. For example, Goldman Sachs \& Co. became embroiled in a scandal over the Goldman Sachs Trading Corp., an investment fund that collapsed in the Great Depression amid accusations of fraud and insider trading. These and other real and perceived abuses again led Congress to act by passing the Securities Act of 1933 and the Securities Exchange Act of 1934, among other laws. These two acts as amended over the years are now among the main federal laws regulating M\&A activity.

\section{THIRD WAVE OF U.S. MERGER ACTIVITY: THE CONGLOMERATES}

By the early 1960s, large corporations were experiencing increased cash flows and skyrocketing stock prices. Rather than 'waste' corporate cash by paying out dividends, management used excess funds to acquire other companies. However, the federal government began to vigorously enforce antitrust laws in the 1960s (Gallo et al. 2000). Government enforcement prevented mergers between companies in the same line of business. These events cued the conglomerate acquisition craze.

Conglomerate mergers involve two companies in unrelated businesses. A typical 1960s conglomerate merger involved a large corporation acquiring a smaller, poorly-managed corporation. The prevailing finance theorists of the time thought that conglomerates offered several benefits. First, a conglomerate would decrease its financial risk through diversification of businesses within a corporate umbrella. The corporations would now have many products across many markets, reducing the impact of a market downturn on corporate profits. Second, a corporation could expand its product lines and market share through a conglomerate merger. It was also theorized that economies of scale would allow maximization of human

5 15 U.S.C. $\$ 41(2015)$. 
capital and operational resources, allowing management knowledge and capital that could be shared across unrelated businesses.

At the height of the conglomerate craze, from 1967 to 1969 , more than 10,000 companies were acquired; the total number during the 1960s was approximately 25,000 . These acquisitions gave rise to gigantic corporate conglomerates. Consider, for example, the International Telephone and Telegraph Corporation, a manufacturer of telecommunications equipment and operating telephone systems:

From 1960 to 1977, with Harold Geneen at the helm, ITT acquired more than 350 companies - at one time securing deals at the rate of one acquisition per week. The portfolio included well-known businesses such as Sheraton hotels, Avis Rent-a-Car, Hartford Insurance and Continental Baking, the maker of Wonder Bread. Under Geneen's management, ITT grew from a mediumsized business with $\$ 760$ million in sales to a global corporation with $\$ 17$ billion in sales. (History of ITT 2015)

By the early 1970s, it was clear that the touted benefits of conglomerates were not being realized. Conglomerates needed to 'keep buying companies and writing up earnings. It was magic, until the pyramid became top-heavy and fell' (Brooks 1998: 97). Diversification of businesses within a corporate entity did not yield the expected profits. Companies' managements could not develop their vast empires and control the various enterprises within the empires. The conglomerate bubble burst. Corporations began exploring ways to divest business divisions and break conglomerates up into manageable segments. This gave rise to the fourth wave of takeover activity: 'going-private' transactions.

\section{FOURTH WAVE OF U.S. MERGER ACTIVITY: HOSTILE TAKEOVERS AND THE RISE OF PRIVATE EQUITY}

In the 1970s and 1980s, takeover activity exploded into the popular consciousness. It was prominently featured not only in the media but also in Hollywood movies. Scholars, politicians, and market participants also commented extensively on the subject. This period featured high-stakes hostile takeovers, defense mechanisms with evocative names such as the 'poison pill', the dramatic rise of private equity, and innovative forms of financing, mainly the leveraged buyout. The fourth wave of takeover activity focused on unwinding the 1960s' corporate conglomerates. By 1977, 53 percent of all U.S. takeovers were the result of conglomerate divestitures - a company was being acquired from a conglomerate. Conglomerate divestitures were given substantial impetus by the creation 
of the 'junk bond' market by Drexel Burnham Lambert's Michael Milken and the ready financing he provided. Junk bonds are bonds rated below investment grade, but Milken was able to attract sources of capital that had previously considered junk bonds too risky. This new capital was available to fund merger and acquisition transactions, including some by acquirers that would otherwise have had difficulty obtaining capital from more traditional sources.

Corporations came under siege during the early 1980s. Acquirers initiated unsolicited hostile acquisitions through cash tender offers financed by junk bonds. Contested tender offers increased from 12 in 1980 to 46 in 1988 (Salter and Winhold 1980). No company was safe as acquirers aimed for bigger and bigger targets: of the Fortune 500 companies in 1980, at least 28 percent were acquired by 1989 (Shleifer and Vishny 1991). Acquisition attempts were quick and public, catching unsuspecting management off guard. T. Boone Pickens, Carl Icahn, Ronald Perelman, and other so-called 'corporate raiders', developed innovative bidding tactics and takeover methods to enable them to expedite the acquisition process. In response, target boards implemented defensive measures, including poison pills, shark repellents, Pac-Man defenses, golden parachutes, and greenmail. ${ }^{6}$ The Delaware courts approved the use of defensive mechanisms in hostile acquisitions, in particular poison pills, arming target boards with tools to fight raiders' bids. Indeed, M\&A's core legal doctrines developed between the late 1970s and late 1980s as a result of the heightened number of takeovers and the creativity of bidders and targets. The fourth wave of takeover activity thus had a fundamental impact on modern M\&A which is still seen today.

The 1980s also saw the rise of leveraged buyout firms, now known as private equity firms. Between 1985 and 1989, more than 1,625 private equity buy-outs or 'going-private' transactions occurred. The 1980s private equity firms were 'lean, decentralized organizations with relatively few investment professionals and employees' (Kaplan and Strömberg 2009: 123) The first such firm was Kohlberg, Kravis, Roberts \& Co. (KKR), formed in 1976. Private equity firms solicited investors, primarily pension funds, pooling their money to acquire underperforming companies. They charged annual management fees and acquisition fees as well as fees to monitor the companies they acquired. Private equity firms were thus intimately involved in the operations of these companies. Management accountability, operations outside of public markets, long-term financial

6 Latham and Watkins' Book of Jargon, available at http://www.lw.com/ bookofjargon-apps/BOJ-GlobalMandA is a useful glossary of M\&A terms. 
goals, and leverage allowed private equity firms to realize high returns on their acquisitions.

KKR pioneered the private equity model using financing from pension funds and junk bonds. During the 1980s, KKR completed 'nearly $\$ 60$ billion in acquisitions, buying companies as diverse as Safeway Stores, Duracell, Motel 6, Stop \& Shop, Avis, Tropicana, and Playtex' (Anders 1992: xv). In 1979, KKR completed its first major leveraged buy-out, of Houdaille Industries for $\$ 380$ million. Fast forwarding ten years, KKR won a bidding war against a management buy-out group to purchase $\mathrm{RJR} /$ Nabisco in a then-record-setting $\$ 31.1$ billion leveraged buyout. That transaction was memorialized in the book and movie, 'Barbarians at the Gate'. At the time, the leveraged buyout (LBO) was a new approach to financing acquisitions. In an LBO, private equity firms borrowed money against the target corporation's assets to finance the purchase of the target corporation. George Anders explained: '[a]s merchants of debt, the KKR men could control a giant company's stock and claim a fat share of eventual profits, at hardly any cost to themselves. All they needed was the audacity to propose and carry out these combinations of borrowed money and borrowed management' (Anders 1992: 21). Private equity firms obtained financing from large commercial banks and from junk bonds to make million- or billion-dollar hostile takeover offers. At one point Michael Milken and his Drexel associates were underwriting \$20 billion in junk bonds annually (Bruck 1989). ${ }^{7}$

KKR's takeover of RJR/Nabisco represented the last major leveragedbuyout transaction of the 1980s. By the late 1980s, the junk bond market crashed in part due to heavy saturation by the debt needed for the RJR/ Nabisco deal: one news account described the junk bond market as 'groaning under an avalanche of RJR Nabisco Inc. securities' (Lenzer 1989). The private equity and leveraged buy-out acquisition wave was over, and takeover activity entered into a quiet period.

\section{THE FIFTH WAVE OF U.S. MERGER ACTIVITY}

The fifth wave of U.S. merger activity, ranging from approximately 1992 to 2001, has been described as the era of the 'mega deal.' During this period, companies of unprecedented global size and scale were created; the size

7 Michael Milken later pleaded guilty to six counts of securities law violations and was sentenced to ten years in prison, a sentence that was reduced to two years. $\mathrm{He}$ also paid $\$ 600$ million in total fines and restitution. 
and number of M\&A deals was largely unprecedented as well (Martynova and Renneboog 2005). Like the preceding waves, it was driven by the buoyancy of the stock market. This wave included the technology (or dot.com) bubble. It came to a halt due to the equity market collapse in 2000, when the bubble burst.

Throughout the fifth wave, there was a strong drive toward larger economies of scale. Several multinational conglomerates were created under the widely held belief that competitive advantage was best achieved through size. This belief motivated mergers between companies such as Chrysler and Daimler-Benz, Exxon and Mobil, Boeing and McDonnell Douglas, Morgan Stanley and Dean Witter, and AOL and Time Warner (Lipton 2006). Large-scale transactions such as these required substantial financing. During this wave, debt became less common as a financing tool, and was replaced with equity.

The strategic transactions of the fifth wave were in part focused around inflated equity securities. During this wave, the stock market values of several large companies took off, and various market indices reached new highs. The technology or dot.com bubble, mentioned above, began in the late 1990s, popping in 2001.

While each takeover wave may originate out of similar circumstances, the individual waves are typically characterized by different transactions and industry concentrations. The fifth wave was no exception.

Certain industries accounted for a disproportionate share of the total dollar volume of M\&A in the United States during the fifth merger wave. In particular, banking and finance and communications and broadcasting accounted for $26.5 \%$ of all U.S. deals over the period of 1993-2004. However, the percentage accounted for in these industries rose from a low of $7.5 \%$ in 1994 to a high of $41.9 \%$ of deals in 1999 . This was caused by a combination of factors including the continued impact of deregulation and consolidation of the banking industry as well as the dramatic changes that were going on in telecom and Internetrelated businesses. The fifth wave would have been different had it not been for the 'inflating' yet short-lived impact of these sectors. (Gaughan 2015: 69)

Roll-ups and consolidations were also a significant feature of the fifth wave. These roll-ups involved the consolidation of fragmented industries through larger-scale acquisitions by companies called 'consolidators'. A group of investment banks began specializing in financing roll-ups and issuing stock in these newly consolidated companies. Roll-ups were intended to combine smaller companies into national-scale businesses so that these companies could market nationally rather than regionally. While these benefits existed in theory, the track record of many of these consolidation deals was poor. 
During the fifth wave, M\&A activity tended to occur between firms in related industries. We also saw the beginnings of international M\&A, something that would come to define merger activity in the sixth wave. The onset of the new millennium, the bursting of the dot-com bubble, the fall of NASDAQ, and the tightening of banking standards on issuing credit, all served to end the fifth wave of M\&A.

\section{THE SIXTH WAVE OF U.S. MERGER ACTIVITY: MODERN M\&A ACTIVITY}

The sixth wave of U.S. merger activity was an era of private equity and cross-border transactions that was relatively short, yet intense, ending abruptly with the financial crisis.

After the collapse of the technology bubble and subsequent global downturn, the U.S. entered a brief recession. The Federal Reserve System lowered its primary interest rate to combat the recession. As the economy recovered, merger activity began picking up. During 2004-2008, deal making became a truly global business. The trade winds of globalization forced businesses to look beyond their national borders for a competitive advantage worldwide. This wave was boosted by the advent of global capital, increased hedge fund activity, an unprecedented wave of liquidity, and the availability of cheap credit due to low interest rates and global savings imbalances. Because of this liquidity and low interest rates, cash replaced stock as the primary acquisition currency (Alexandridis et al. 2012).

Private equity acquirers taking advantage of cheap credit drove the sixth wave. Private equity took off in this era, as shareholders looked to spread the ownership and day-to-day management of their companies between themselves and institutional investors.

In the sixth wave private equity acquirers bought companies (or divisions of companies), waited for the rising market to push up the value of their acquisitions, and then spun them off. And although private equity companies were not new to the M\&A market, private equity buyers became major players during this time due to the low cost of capital. Private equity investors backed more than half of the large transactions concluded in the period. These increasingly targeted technological firms - in deals like the $\$ 1.1$ billion purchase of DoubleClick by Hellman \& Friedman - or teamed up with fund mega-deals, such as the $\$ 10.4$ billion acquisition of SunGard Data Systems. And since the bulk of the financing that paid for these acquisitions was low-interest-rate debt, these firms were able to generate high returns for the equity holders upon disposal. Historically low interest rates therefore not only fueled the growth of the merger wave but also, for the first time, allowed private equity companies to play a significant role in the market. (McCarthy and Dolfsma 2013: 26) 
A substantial proportion of M\&A activity in the sixth wave was crossborder transactions, reflecting the growing globalization of products, services, and capital markets. The sixth wave occurred in the context of deregulation in Asia, market integration in Europe, low interest rates, and a historically weak dollar (DePamphilis 2008). The result was heightened cross-border investment. Developing nations' entry into the M\&A market became increasingly important in modern M\&A. During the sixth wave, China, India, and Brazil emerged as global players in trade and industry, making cross-cultural negotiation skills a central component of the crossborder M\&A practice.

The sixth wave ended in 2008, as credit became more expensive, and, more dramatically, as the financial crisis began. From 2008 to 2010, M\&A activity sank to its lowest levels since 2004. It took quite a while for M\&A activity to recover to pre-financial crisis levels, as companies remained hesitant to pursue risky M\&A transactions. But as this chapter is being written, in mid-2016, transaction volume is now on an upward trajectory. In particular, we are seeing some large-scale M\&A transactions occur as certain industries contract into a small number of key players, including the telecommunications and cable industries. In addition, corporations continue to engage in M\&A regulatory arbitrage. The recent wave of tax inversions - companies acquiring foreign companies and reincorporating abroad - is illustrative of this trend. Meanwhile, internet companies like Google and Facebook are reviving conglomerates through large-scale investment in a variety of different technologies. It appears that the latest wave of M\&A (which is increasingly being called the seventh wave) will be characterized by the creation of oligopolies that is industries dominated by only a few key players - as well as increasing internationalization.

In addition, the time after the sixth wave has been characterized by increasing shareholder activism. The rise of hedge funds actively engaged in M\&A has in some minds replaced the hostile takeover market. In any given year in the United States, roughly 5 percent of public takeover transactions are hostile (Cain et al. 2015) or roughly 15-30 transactions. Meanwhile, the rate of shareholder activism has climbed to over 400 incidents a year according to Factset Sharkrepellent. The drift toward shareholder activism has impacted takeover law, as laws from the 1980s are revised to take into account the activism phenomenon. 


\section{CONCLUSION}

The rich history of M\&A, with its alternating cycles of activity and quiescence, illustrates an important role for law. The law is both a response to M\&A activity, implementing ex post facto regulation, and a guiding force, spurring waves of M\&A activity throughout. There is no doubt that as M\&A continues its cyclical life, the law, lawyers and those who study the law will continue to play an important part in this economic phenomenon. From its origins - when law mattered little - M\&A has become a highly regulated business.

\section{BIBLIOGRAPHY}

Alexandridis, George, et al. (2012). 'How Have M\&As Changed? Evidence from the Sixth Merger Wave', European Journal of Finance, 18, 663-688.

Anders, George (1992). Merchants of Debt: KKR and the Mortgaging of American Business. Beard Books.

Baldwin, Robert E. and L. Alan Winters (2004). Challenges to Globalization: Analyzing the Economics. University of Chicago Press.

Ballam, Deborah A. (1994). 'The Evolution of the Government-Business Relationship in the United States: Colonial Times to Present', American Business Law Journal, 31, 553-640.

Brooks, John (1998). The Go-Go Years: The Drama and Crashing Finale of Wall Street's Bullish 60s. Allworth Press.

Bruck, Connie (1989). Predators Ball: The Inside Story of the Rise of Drexel Burnham and the Rise of the Junk Bond Raiders. Penguin.

Cain, Matthew D., et al. (2015). 'Do Takeover Laws Matter? Evidence from Five Decades of Hostile Takeovers', AFA 2015 Boston Meetings. Available at SSRN: http://papers.ssrn. com/sol3/papers.cfm?abstract_id=2517513

Commentary (1930). 'Judicial Interpretation of $\S 7$ of the Clayton Act', Yale Law Journal, $39,1042-50$.

DePamphilis, Donald (2nd edn 2008). Mergers, Acquisitions, and Other Restructuring Activities. Academic Press.

Gallo, Kenneth et al. (2000). 'Department of Justice Antitrust Enforcement 1955-1997: An Empirical Study', Review of Industrial Organization, 17, 75-133.

Gaughan, Patrick A. (5th edn 2015). Mergers, Acquisitions, and Corporate Restructurings. John Wiley and Sons.

Gotts, Ilene Knable, et al. (2005). 'Nature vs. Nurture and Reaching the Age of Reason: The U.S./E.U. Treatment of Transatlantic Mergers', New York University Annual Survey of American Law, 61, 453-508.

History of ITT (2015). International Telephone and Telegraph Corporation, available at http://www.itt.com/about/history/

Kaplan, Steven N. and Per Strömberg (2009). 'Leveraged Buyouts and Private Equity,' Journal of Economic Perspectives, 22, 121-146.

Lenzer, Robert (Mar. 19, 1989). 'RJR Nabisco Issue May Bring Junk Bonds Into the Mainstream', The Chicago Tribune, available at http://articles.chicagotribune. com/1989-03-19/business/8903270950_1_ostrander-capital-rjr-nabisco-junk-bonds

Lipton, Martin (Sept. 14, 2006). 'Merger Waves in the 19th, 20th and 21st Centuries', The Davies Lecture at Osgoode Hall Law School, York University, available at http:// cornerstone-business.com/MergerWavesTorontoLipton.pdf

Martynova, Marina and Luc Renneboog (Sept. 2005). 'Takeover Waves: Triggers, Performance 


\section{Research handbook on mergers and acquisitions}

and Motives', CentER Discussion Paper; Vol. 2005-107; TILEC Discussion Paper, available at https://pure.uvt.nl/portal/files/776337/107.pdf

McCarthy, Killian J. and Wilfred Dolfsma (2013). Understanding Mergers and Acquisitions in the 21st Century: A Multidisciplinary Approach. Palgrave Macmillan.

Moody, John (1904). The Truth About the Trusts: A Description and Analysis of the American Trust Movement. Moody Publishing Company.

Salter, Malcolm and Wolf Winhold (1980). Merger Trends and Prospects of the 1980s. U.S. Department of Commerce.

Shleifer, Andrei and Robert W. Vishny (1991). 'Takeover in the '60s and the '80s Evidence and Implications', Strategic Management Journal, 12, 51-59.

Stover, John F. (2nd edn 1997). American Railroads. University of Chicago Press. 